\title{
A point of view on genetic resources and plant breeding
}

\author{
Alejandro Salvio Escandon ${ }^{1,2^{*}}$ (C) \\ ${ }^{1}$ Plant Breeding and New Crops Area-Editor, Ornamental Horticulture, Viçosa-MG, Brazil \\ ${ }^{2}$ Instituto Nacional de Tecnología Agropecuaria, Buenos Aires, Argentina.
}

Biodiversity is the set of living organisms that make up our battered planet and their interactions with the environment. It is made up of the Kingdoms: Animalia, Plantae, Fungi, Protista, and Monera.

It provides the energy resources necessary to sustain the planet and our civilization; it is the basis of agriculture, source of all crops, and species of domestic livestock since the beginning of human civilization.

It is possible to describe biodiversity from three different levels: ecosystems, species, and genes. Each of these components has its composition and structures. Through technological progress, humanity has been modifying the way it takes advantage of biodiversity. From using the ecosystem, being hunters/collectors, domesticating several species with the advent of agriculture and livestock, and, today, modifying genes through the development of NBTs.

Since its origin, humanity has used the Plantae kingdom as a source for its food, its drinks, its pharmacy, its rituals, and its ornament. With the beginning of agriculture, human beings have selected from the natural populations the most suitable individuals for their benefit, made directed crosses, selecting what is considered appropriate, and discarding the rest. This was carried out without restrictions of any kind.

Until the CBD and its complementary agreement, the Nagoya Protocol, entered into force, genetic resources belonged to humanity with no rules governing their access and rational use. There are many examples of ornamental varieties, native to South America, in the world market for which royalties must be paid for their commercialization in the country of origin.

The market for ornamental plants is very demanding and eager for novelties, South America is a megadiverse region. It accounts for about 600 ornamental plant species $(12 \%$ garden plants). Popular ornamental plants that originated from this center are Anthurium, Calendula, Dieffenbachia, Philodendron, Gloxinia, Caladium hybridum, Salvia splendens, Heliotropium arborescens, Verbena hybrida, and morning glory (Ipomoea alba, I. purpurea and I. tricolor) (De, 2017). Within the framework of the CBD and Nagoya, ornamental GRs are potentially a source of new varieties for that market, with the consequent socioeconomic impact on the region for the generation of direct and indirect employees of different qualifications.

On the other hand, the scenario generated by global climate change, the scarcity of quality water for irrigation, the advance of urbanization with the consequent displacement of cultivation areas, and the potential appearance of biotic stress-generating factors (new pests or diseases) and abiotic (lack of water and/or contamination of the water table), force the search for new variability for the development of genotypes that adapt to these new conditions.

In this context, ornamental native phyto genetic resources play a double role, either through their incorporation into the market as a new variety or by providing the genes that confer tolerance to the stress situations mentioned above to the cultivated varieties.

The incorporation of new varieties to the market would require adding added value and this is achieved, among other alternatives, with genetic improvement, to give it variability in colours, shapes, sizes, different architecture, post-harvest life, among other traits.

As an example, two South American countries, Brazil (Vichiato and Vichiato, 2017) and Argentina (INTA, 2021) are generating exploratory studies, development programs, and market strategies to launch their improved native varieties on the market, following all requisites of CDB and Nagoya Protocol.

As a discipline for "directed plant evolution", plant breeding has several tools to increase genetic variability, from classical cross-breeding to NBTs, through induced mutations and transgenicity, all these disciplines can generate novelties for both, the market and the producers. In this context, it would be interesting to note that all tools used by humanity for genetic improvement, classical crossing, artificial mutations, transgenesis (crosssectional gene transfer), and gene editing, are not "human inventions". They are the product of the observation of natural phenomena and their adaptation to the needs of human beings.

Most of the ornamental plants have been obtained from inter-specific and inter-generic crosses, which lead to a high degree of heterozygosity in the resulting hybrids. The goal in ornamental plant breeding is to improve variety traits, novel color, architecture, size, number of flowers, flower vase life, repeat blooming, disease resistance, nutrient uptake capacity, growth habit, and the introgression of genes of interest from wild material.

Herein, it is important to remark that classical crossbreeding may be complemented and helped by

*Corresponding author: escandon.alejandro@inta.gob.ar 
biotechnology tools as molecular markers, which is a proven alternative to accelerate selection processes. Likewise, for both intra- and interspecific crosses, including intergeneric crossings, the basis, and potential of this strategy are amplified by the support that in vitro tissue culture can provide. The culture of anthers to obtain homozygous lines, the rescue of embryos to make incompatible crosses viable, and the acceleration of generations in vitro, are techniques that significantly shorten the process of selecting individuals are some examples.

When the crossing is not viable, the obtaining of mutants by irradiation or chemical mutator (Kishi-Kaboshi et al., 2018) or polyploids using colchicine or another chemical (Van Tuyl and Lim, 2003), are alternative methods to generate randomly increasing genetic variability and then selecting individuals according to the trait sought.

For his part, transgenic or cisgenic strategies allow the introduction of a gene that codes for a desired trait on a given genetic background, avoiding the lost or dilution of the original phenotype. This would accelerate the times of obtaining a new line. At least 50 ornamental plants have been transformed, including rose (Rosa hybrida), chrysanthemum (Chrysanthemum morifolium), petunia (Petunia hybrida), and carnation (Dianthus caryophyllus) (Boutigny et al., 2020). However, the deregulation times that these crops have and the problems generated by the perception of the public do not facilitate the release of these new varieties, despite presenting the same ecological risk as a hybrid obtained by crossing or a mutant artificially obtained.

In recent years, with the advent of gene editing and the emergence of gene-editing systems, there has been a quantitative and qualitative leap in all areas of molecular biology, including plant breeding. This system is used, under in vitro conditions, to edit genes based on the production of double-stranded breaks and its subsequent repair allows genomes to be edited very precisely.

There are some examples of flower colour ornamental plants modified via CRISPR/Cas9 technology. Chrysanthemum morifolium, Dendrobium officinale, Imonema nill, and Petunia hybrida (Kishi-Kaboshi et al. 2018). Indeed, this system makes it possible to silence genes, correct errors in the sequence, or incorporate new ones. It has been a very short journey so far, and in many countries, it is being discussed how to evaluate the nature of the products obtained from this technology soon.

As a final reflection, it is relevant to emphasize that humanity, as part of biodiversity, has evolved to the point where it is able to observe, learn, and use, for its benefit, the process developed by nature to generate genetic variability and address the evolution of species of economic interest. However, a drastic change in the productive paradigm is necessary for safeguarding the genetic resources, making reasonable and sustainable use of them, in order not to continue eroding the biodiversity that, as indicated at the beginning, is the sustenance of our civilization.

\section{References}

BOUTIGNY, A.L.; DOHIN, N.; PORNIN, D.; ROLLAND, M. Overview and detectability of the genetic modifications in ornamental plants. Horticulture Research, v.7, n.11, p.1-12, 2020. https://doi.org/10.1038/s41438-019-0232-5

DE, L.C. Improvement of Ornamental Plants - a Review. International Journal of Horticulture, v.7, n.22, p.180-204, 2017. https://doi.org/10.5376/ijh.2017.07.0022

INTA. 2021. Variedade ornamentales INTA. Available in: <https://inta.gob.ar/paginas/variedades-ornamentales-inta> Accessed on: September 13, 2021.

KISHI-KABOSHI, M.; AIDA, R.; SASAKI, K. Genome engineering in ornamental plants: current status and future prospects Plant Physiology and Biochemistry, v.131, n.47, p.47-52, 2018. https://doi.org/10.1016/j.plaphy.2018.03.015.

VAN TUYL, J.M.; LIM, K-B. Interspecific hybridisation and polyploidisation as tools in ornamental plant breeding. Acta Horticulturae, n.612, p.13-22, 2003. https://doi.org/10.17660/ActaHortic.2003.612.1

VICHIATO, M.R.M.; VICHIATO, M. Espécies herbáceas e arbustivas ornamentais nativas da flora brasileira em Belo Horizonte, Minas Gerais. Tecnologia e Ciência Agropecuária, v.11, n.1, p.1-9, 2017. 